U.S. DEPARTMENT OF THE INTERIOR

U.S. GEOLOGICAL SURVEY

\title{
EARTHQUAKE INFORMATION NEEDS IN SOUTH-CENTRAL ALASKA
}

by

Robert A. Page ${ }^{1}$ and Peter J. Haeussler ${ }^{2}$

Open-File Report 95-696

This report has not been reviewed for conformity with U.S. Geological Survey editorial standards. Any use of firm names is for descriptive purposes only and does not imply endorsement by the U.S. Government.

${ }^{1}$ U.S. Geological Survey, MS 977

345 Middlefield Road

Menlo Park, CA 94025
${ }^{2}$ U.S. Geological Survey

4200 University Drive

Anchorage, AK 99508-4667 


\section{INTRODUCTION}

The U.S. Geological Survey (USGS) sponsored a one-day customer workshop in February 1995 to identify earthquake information needs in south-central Alaska. The workshop solicited views regarding what types and formats of earthquake information are needed to reduce losses and impacts in future earthquakes, particularly from shocks threatening the Anchorage-Cook Inlet region. These views were sought in preparation to framing a new multiyear plan for earthquake studies in Alaska supported by the USGS Earthquake Hazards Reduction Program (EHRP).

To speed the reduction of future earthquake losses and impacts, the USGS is largely concentrating EHRP activities where the risks are highest, that is, in the nation's earthquake-prone urban areas. Consistent with this strategy, the EHRP is refocusing its earthquake activities in Alaska to place more emphasis on providing information and products that will contribute to reducing future losses and impacts in the most populated areas of Alaska, particularly the Anchorage region of south-central Alaska.

The workshop brought together in Anchorage a broad audience of users and providers of earthquake information (Appendix 1). Thirty participants drawn from the private sector and from local, state, and federal government agencies represented users of earthquake information. They included engineers, architects, insurance adjusters, TV media, and disaster and relief planners. Twelve participants, comprising earth scientists and engineers, represented providers of earthquake information. Participants were suggested by a steering committee comprising leaders in the earthquake hazards community (Appendix 2).

Participants representing users of earthquake information were each given several minutes in which to state their perspectives regarding critical needs for earthquake information (Appendix 2). Each presentation was followed by a brief period of questions and discussion. Participants representing providers of information were asked to listen to the views of the users of information, to respond to questions, and to clarify technical issues. All workshop participants were asked to summarize their views in a two- to three-page letter to be written after the workshop.

This report summarizes earthquake information needs identified in the workshop discussion, in followup letters, and in comments on the preliminary draft of the workshop report, which was sent to all participants. 


\section{SUMMARY OF EARTHQUAKE INFORMATION NEEDS}

The workshop participants identified a broad spectrum of needs and issues related to earthquakes and earthquake information, and even to other earth-science issues, such as volcano monitoring. Most of the needs can be summarized under the following themes. A full list of needs identified by users of earthquake information is provided in Appendix 3.

Earthquake hazard maps and GIS-database for the Anchorage Bowl

A particular need for the Anchorage Bowl is a folio of maps at 1:25,000-scale or larger to depict earthquake-related hazards and an underlying GIS-database that integrates all the earth-science, engineering, land-use, building and infrastructure information needed to assess and map earthquake-related hazards and potential earthquake losses and impacts. In addressing earthquake-related hazards, the municipality relies heavily on a seismically-induced ground-failure map prepared by Harding-Lawson Associates in 1979 that is based on information from USGS maps published in the early 1970s. A wealth of new geologic and geotechnical information has become available over the last 20 years. New information on shaking response is currently being gathered. All these data should be assembled into a GIS-database and used to prepare a folio of maps depicting various hazards and conditions, including ground shaking, liquefaction susceptibility, seismic slope stability, surface and subsurface geology and hydrology, and geotechnical properties to depths of $300 \mathrm{ft}$ or more. These data can be combined with information on existing buildings and infrastructure to assess the impacts of and potential losses from future earthquakes.

Knowledge of the earthquake potential

Fundamental to more accurate and reliable assessments of earthquake hazard and risk is better knowledge of the location, magnitude, and rate of occurrence of large earthquakes that could threaten population centers or critical facilities or systems. Although earth scientists have defined several major fault systems capable of generating earthquakes, there are many seismically capable faults yet to be resolved. Even for the known active faults there is little information relating to long-term slip rates and dates of prehistoric earthquakes on which to base hazard evaluations. Questions of particular importance are the recurrence rates of major earthquakes along the Pacific margin and the location of active faults and folds in the shallow crust, particularly in the Cook Inlet-Anchorage region.

Statewide probabilistic maps of earthquake shaking hazard

New probabilistic shaking hazard maps of Alaska are needed for use in seismic design. The 1990 USGS maps of acceleration and velocity for Alaska by Algermissen and co-workers are based on seismotectonic models, fault information, and distance-attenuation relations dating from the early $1980 \mathrm{~s}$ and 1970s and are at a small scale $(1: 17,000,000)$. More recent information should be incorporated into new maps produced at a larger scale.

\section{Strong-motion data}

The strong-motion database, underlying current engineering design standards, is deficient in records from major subduction-zone earthquakes. Strong-motion records are needed to characterize the nature and duration of shaking that occurs in and near the source region of interplate thrust-type earthquakes larger 
than magnitude 7.0. Strong-motion records are also needed from representative sites in the Anchorage region to validate and calibrate methods for predicting shaking in the Anchorage Bowl.

\section{Tsunami run-up hazard}

Tsunamis have accounted for most of the deaths in Alaskan earthquakes to date. The greatest hazard is associated with local waves generated by submarine and subaerial slides triggered by earthquake shaking. Information is needed regarding the stability of mountainside and delta-front slopes in populated fiords and bays. Also needed are estimates of wave heights and run-up distances of potential tsunamis.

\section{Earthquake scenarios}

Scenarios of likely effects from plausible damaging earthquakes are needed to evaluate the vulnerability of structures, facilities and operations and to plan disaster response and recovery strategies and actions. This need is most acute in the extended Anchorage region.

\section{Rapid earthquake information and hazard warnings}

Modem regional seismograph networks are capable of providing reliable information about earthquakes and their likely effects within minutes of their occurrence. This rapid information is needed by emergency managers to speed search and rescue activities and by government and the private sector to implement planned emergency procedures that reduce or prevent secondary losses arising from failure of structures and disruption of lifelines and operations. This rapid information is also critical for decisions about the need for support and resources from the lower 48 states. With an adequate on-line database (incorporating geology, geotechnical conditions, land use, buildings, and infrastructure), maps of expected damage patterns can be produced quickly enough to help guide and focus emergency response and relief activities.

\section{Availability and suitability of earthquake-related information}

A comprehensive directory of available earthquake reports for Alaska, or even the Anchorage area, is lacking. An on-line electronic directory is desirable. Most earth-science maps and reports are highly technical and have been written for an audience of discipline specialists. Such products are not easily understood or widely used by professionals in other fields, such as engineers, architects, planners, and disaster response officials. There needs to be more effort to communicate earth-science information and knowledge to both professionals and the public through interpretive and educational products and through workshops, lectures and seminars.

\section{Coordination and cooperation}

The workshop elicited a lot of interest in strengthening coordination, cooperation, and communication between the users and providers of earthquake information. An annual workshop drawing together users and providers of earthquake information could be a forum for discussing earthquake hazard issues and disseminating recent research results and an opportunity for better networking between researchers and practitioners. A regional consortium including government and private interests could substantially accelerate the current rate of progress toward reducing the losses and impacts of future earthquakes in the extended Anchorage region. A multiyear coordinated public education program involving local, state and federal agencies could stimulate and enhance loss reduction activities in both the public and private sectors. 


\section{APPENDIX 1. LIST OF WORKSHOP PARTICIPANTS}

Private Sector

\begin{tabular}{ll}
\hline Mark Anderson & Engineering/ Seismic Coordinator \\
Dennis Berry & Vice President/Structural Engineer \\
Joyce Brinkley & Director, Disaster Services \\
David Cole & Geotechnical engineer \\
Jon Kumin & Principal Architect \\
Robert Love & Partner, Insurance Adjuster \\
Mark Marlow & Construction Manager \\
William Nagengast & Senior Project Engineer \\
Tim Woolston & Assistant News Director
\end{tabular}

Municipal/Borough Government

\begin{tabular}{ll}
\hline Tom Bibeau & Risk Manager \\
Ingrid Green & Safety Coordinator \\
Michael Mason & Plan Review Engineer \\
Judith Pinkston & Senior Administrative Officer \\
Robert Stewart & Director \\
Dick Traini & Chairman \\
George Vakalis & Operations Manager \\
Ron Watts & Chief, Building Inspections \\
John Duffy & Planning Director
\end{tabular}

State Government

Francis Allan

Rodney Combellick

Roger Head

Dick Meyer

Christy Miller

Dan Peavey

Mike Webb

Federal Government

Michael Besancon

Tod Hartung

Doug Lalla

Regan Sarwas

Thomas Sokolowski

Nirendra Biswas

L. David Carter

Rodney Combellick

Peter Haeussler

Roger Hansen

John Lahr

Robert Page

Thomas Pratt

Thomas Sokolowski

Mohamad Succarieh

Randall Updike

Max Wyss
Administrative Officer

Chief, Engineering Geology Section

Chief, Public Facility Branch

Physical Plant Manager

Flood Insurance Program Coordinator

Foundation Materials

Earthquake response planning

Director, Plans and Policy

Senior Staff Officer, Current Ops

Seismologist, Pipeline Monitoring Office

Structural Engineer

Chief

\section{USERS OF EARTHQUAKE INFORMATION}

Alyeska Pipeline Service Company

Andersen Bjornstad Kane Jacobs

American Red Cross

Dowl Engineers

Kumin Associates, Inc., Architects and Planners

Love and Associates

Denali Commercial Management, Inc.

Chugach Electric Association, Inc.

KTUU Television (Channel 2)

Anchorage School District

Anchorage Water \& Wastewater Utility

Anchorage Dept. Public Works

Anchorage Municipal Light \& Power

Anchorage Office of Emergency Management

Anchorage Assembly

Municipality of Anchorage

Anchorage Dept. Public Works

Matanuska-Susitna Borough

\begin{abstract}
Alaska State Troopers
AK Div. Geol. \& Geophys. Surveys

AK Dept. Transport. \& Public Facilities

Anchorage International Airport

Dept of Community \& Regional Affairs

AK Dept. Transport. \& Public Facilities

Division of Emergency Services
\end{abstract}

PROVIDERS OF EARTHQUAKE INFORMATION

Professor of Geophysics

Chief, Branch of Alaskan Geology

Chief, Engineering Geology Section

Geologist

Alaska State Seismologist

Seismologist

Seismologist

Geophysicist

Chief

Asst. Prof. of Civil Engineering

Chief, Branch Earthquake/Landslide Haz.

Seismologist
Alaskan Command

Alaskan Command

Bureau of Land Management

Corps of Engineers, Alaska

Alaska Tsunami Warning Center
Geophysical Institute, Univ. of Alaska

U.S. Geological Survey

AK Div. Geol. \& Geophys. Surveys

U.S. Geological Survey

Geophysical Institute, Univ. of Alaska

U.S. Geological Survey

U.S. Geological Survey

U.S. Geological Survey

Alaska Tsunami Warning Center

University of Alaska

U.S. Geological Survey

Geophysical Institute, Univ. of Alaska 


\section{STEERING COMMITTEE}

Robert Page, Chair John Aho David Cole Rodney Combellick Peter Haeussler Roger Hansen Roger Head Michael Mason
U.S. Geological Survey, Menlo Park, CA $\mathrm{CH} 2 \mathrm{M}$ Hill, Anchorage Dowl Engineers, Anchorage Alaska Division of Geological and Geophysical Surveys, Fairbanks U.S. Geological Survey, Anchorage Alaska State Seismologist, Geophysical Institute, Fairbanks Alaska Department of Transportation/Public Facilities, Anchorage Anchorage Department of Public Works, Anchorage

\section{WORKSHOP AGENDA}

EARTHQUAKE INFORMATION NEEDS IN SOUTH-CENTRAL ALASKA

ANCHORAGE, ALASKA

WEDNESDAY, 22 FEBRUARY 1995

\footnotetext{
08:30 INTRODUCTION -- $30 \mathrm{~min}$

09:00 OVERVIEW OF USGS EHRP -- $45 \mathrm{~min}$

The National Earthquake Hazards Reduction Program (NEHRP)

The USGS Earthquake Hazards Reduction Program (EHRP)

EHRP activities in Alaska

Increased NEHRP emphasis on loss reduction

09:45 *** Break *** $15 \mathrm{~min}$

10:00 NEEDS OF PRIVATE SECTOR -- $120 \mathrm{~min}$

12:00 *** Buffet Lunch *** $60 \mathrm{~min}$

13:00 NEEDS OF MUNICIPALITY AND BOROUGHS -- $70 \mathrm{~min}$

14:10 NEEDS OF STATE AGENCIES -- $60 \mathrm{~min}$

15:10 *** Break *** $20 \mathrm{~min}$

15:30 NEEDS OF FEDERAL AGENCIES .- $50 \mathrm{~min}$

16:20 WRAP-UP -. $40 \mathrm{~min}$

17:00 ADJOURN
} 


\section{APPENDIX 3. LIST OF EARTHQUAKE INFORMATION NEEDS}

The following is a list of needs summarized from verbal and written statements of users of earthquake information.

\section{Anchorage Bowl}

- Maps of the capability of the shallow geology to amplify ground shaking relative to bedrock (1:25,000 scale or larger).

- Maps of shaking hazard incorporating earthquake potential and amplification effects of shallow geology (1:25,000 scale or larger).

- Records of strong ground motion from multiple surface sites and from vertical instrument arrays to verify and refine ground motion models.

- Time histories of strong ground motion from representative earthquakes recorded at representative sites.

- Updated map of liquefaction susceptibility (1:25,000 scale or larger).

- Updated map of seismic slope-stability and zones of potential ground deformation (1:25,000 scale or larger).

- Information on seismic stability of coastal areas and marine channels.

- Updated map of surficial geology (1:25,000 scale or larger).

- Information on depth to bedrock and subsurface shear-wave velocity.

- Information on depth to water table.

- Compilation and synthesis of subsurface geologic/geotechnical information to depth of about 300 feet from all available sources (government and private).

- GIS (Geographic Information System) database of geologic and geotechnical information.

\section{Extended Anchorage Region}

- Scenarios of shaking and geologic effects for plausible large shocks for use in assessing the vulnerability of existing structures and lifeline systems, and in planning disaster response and recovery operations.

- Maps of active faults (1:63,360 or larger, except 1:25,000 scale or larger in developed or developable areas).

- Information on active faults including rates of episodic slip and continuous creep, dates and rupture lengths of prehistoric earthquakes, earthquake recurrence rates, and magnitudes of maximum likely events. The Castle Mountain fault system is a high priority target.

- Determination of whether the Border Ranges fault system is capable of producing earthquakes.

- Information on buried, shallow earthquake sources including earthquake recurrence rates and magnitudes of maximum likely events. The fold belt in the northem Cook Inlet basin is a high priority target.

- Improved seismic monitoring to delineate earthquake sources and to provide rapid information on earthquakes and likely damage patterns.

- GPS (Global Positioning System) geodetic control framework.

- Information on patterns and rates of crustal deformation. 


\section{South-Central Alaska}

- Information on dates, magnitudes and recurrence rates of major prehistoric interplate megathrust earthquakes.

- Information on recurrence rates and maximum magnitudes of earthquakes occurring in the subducted plate.

- Information on attenuation and duration of strong ground motion.

- Strategies for incorporating the effects of duration of shaking into the seismic provisions of building codes.

- Information on earthquake hazards, surficial geology, and geotechnical properties of foundation materials along transportation corridors.

- Information on the potential for submarine and subaerial slides that could generate local tsunamis which would inundate coastal communities.

- Estimates of wave heights and run-up distances of tsunamis from both local slides and tectonic deformation of the seafloor.

- Digital elevation data.

\section{$\underline{\text { Statewide }}$}

- Updated and refined map of earthquake shaking hazard, incorporating new information about earthquake sources, earthquake recurrence rates, and attenuation of shaking (1:7,500,000 scale or larger).

- Popular editions of earthquake hazard maps for general public.

- Better knowledge of earthquake potential, shallow earthquake sources, and large-scale tectonic processes causing earthquakes.

- Map and electronic database of active faults.

- Regional geologic maps (1:250,000-scale quadrangles).

- Records of strong ground motion near the source zones of large megathrust earthquakes.

- Analysis of the suitability/applicability of seismic provisions of current model building codes, which are based mainly on experience with earthquakes in California, to the conditions in Alaska.

- Analysis of the difference in engineering implications of subduction-zone earthquakes with respect to shallow continental (intraplate) earthquakes.

- Evaluation of the seismic stability of dams whose failure would threaten a population center.

- Faster determination of the location, magnitude, tsunami potential, and damage potential of large earthquakes.

- Rapid automated notification of earthquakes and their potential effects.

- Rapid, complete and reliable post-earthquake damage information.

- Clearinghouse for accurate earthquake information in a disaster situation.

- Better coordination of earthquake response plans.

- On-line electronic catalogs and maps of historic and recent seismicity available via Intemet or fax.

- Printed and electronic catalogs of published earthquake reports and databases.

- Coordination of earthquake-related studies to speed progress and avoid duplication of effort.

- Knowledge of the appropriate design snow load for seismic design in Alaska. 


\section{Information Transfer/Education}

- Timely, user-friendly maps and monographs summarizing and interpreting results and conclusions of detailed technical and scientific studies in a form suitable for direct use by engineers, planners, corporate managers and government officials.

- Regional earthquake consortium to focus and promote efforts to reduce future earthquake losses in the extended Anchorage region.

- Network of professionals engaged in evaluating earthquake hazards and reducing future earthquake losses.

- Annual (or more frequent) workshops of professionals to exchange information regarding state of knowledge and practice regarding earthquake hazards and loss reduction issues. For example, a workshop on the earthquake potential of the Castle Mountain fault.

- Directory of agencies and institutions engaged in earthquake studies, earthquake loss reduction, and earthquake disaster response planning.

- Directory of speakers available to educate professional groups and the public about earthquakes and earthquake loss reduction.

- Information for public service announcements through the media.

- Revision of public education materials developed outside Alaska to address situations unique to Alaska.

- Continuing education seminars and lectures on earthquake issues for professionals and the public.

- Training local communities to prepare for and respond to earthquake emergencies. 